\title{
MILK Symposium review: Foodborne diseases from milk and milk products in developing countries-Review of causes and health and economic implications*
}

\author{
D. Grace, ${ }^{1,2}$ F. Wu, ${ }^{3} \odot$ and A. H. Havelaar ${ }^{4} \dagger$ () \\ ${ }^{1}$ Animal and Human Health Program, International Livestock Research Institute, Nairobi, Kenya 00100 \\ ${ }^{2}$ Natural Resources Institute, University of Greenwich, Central Avenue, Chatham Maritime, Kent, ME4 4TB United Kingdom \\ ${ }^{3}$ Department of Food Science and Human Nutrition, Department of Agricultural, Food, and Resource Economics, Michigan State University, \\ East Lansing 48824 \\ ${ }^{4}$ Animal Sciences Department, Emerging Pathogens Institute, Institute for Sustainable Food Systems, University of Florida, Gainesville 32605
}

\begin{abstract}
Dairy production is rapidly increasing in developing countries and making significant contributions to health, nutrition, environments, and livelihoods, with the potential for still greater contributions. However, dairy products can also contribute to human disease in many ways, with dairyborne disease likely being the most important. Health risks may be from biological, chemical, physical, or allergenic hazards present in milk and other dairy products. Lacking rigorous evidence on the full burden of foodborne and dairyborne disease in developing countries, we compiled information from different sources to improve our estimates. The most credible evidence on dairyborne disease comes from the World Health Organization initiative on the Global Burden of Foodborne Disease. This suggests that dairy products may has been responsible for 20 disabilityadjusted life years per 100,000 people in 2010. This corresponds to around $4 \%$ of the global foodborne disease burden and $12 \%$ of the animal source food disease burden. Most of this burden falls on low- and middleincome countries (LMIC). However, the estimate is conservative. Weaker evidence from historical burden in high-income countries, outbreak reports from LMIC and high-income countries, and quantitative microbial risk assessment suggest that the real burden may be higher. The economic burden in terms of lost human capital is at least US\$4 billion/yr in LMIC. Among the most important hazards are Mycobacterium bovis, Campylobacter spp., and non-typhoidal Salmonella enterica. The known burden of chemical hazards is lower

Received February 6, 2020.

Accepted April 15, 2020.

*Presented as part of the MILK Symposium: Improving Milk Production, Quality, and Safety in Developing Countries at the ADSA Annual Meeting, Cincinnati, Ohio, June 2019.

†Corresponding author: ariehavelaar@ufl.edu
\end{abstract}

but also more uncertain. Important chemical hazards are mycotoxins, dioxins, and heavy metals. Some interventions have been shown to have unintended and unwanted consequences, so formative research and rigorous evaluation should accompany interventions. For example, there are many documented cases in which women's control over livestock is diminished with increasing commercialization. Dairy co-operatives have had mixed success, often incurring governance and institutional challenges. More recently, there has been interest in working with the informal sector. New technologies offer new opportunities for sustainable dairy development.

Key words: milkborne disease, developing country, pathogen

\section{INTRODUCTION}

Dairy production is rapidly increasing in developing countries, making significant contributions to health, nutrition, environment, and livelihoods, and it has the potential to make still greater contributions. At the same time, there are negative effects associated with dairy production, processing, and consumption. This paper focuses on one of the most important negative effects: human diseases that can be transmitted through milk and dairy product consumption. We focus on bovines which produce $96 \%$ of the world's milk (FAO, 2020). In this review, we describe the main health, nutrition, and other benefits of milk to place the health risks in a broader perspective. Next, we set out some important concepts that are needed to understand the health implications of dairyborne disease, including differentiating safety and quality, hazard and risk, and dairyborne diseases and diseases associated with dairy. Until the last century, milk was an important source of foodborne pathogens, which pasteurization and other hygienic technologies and practices helped to overcome. We describe evidence streams that can contribute to 
understanding milkborne disease, concluding that milkborne disease is likely to be an important public health issue in developing countries, but evidence on the burden is incomplete.

One of the most comprehensive and credible studies on foodborne contaminants is the Global Burden of Food-Borne Disease Initiative, under the aegis of the World Health Organization (WHO); we summarize its findings relevant to milkborne disease. The next section focuses on aflatoxin, a fungal toxin, of which a metabolite frequently appears in dairy products worldwide. We then review the scant literature on the economic implications of milkborne disease. The final section summarizes some of the approaches and options for reducing the burden of milkborne disease.

\section{HEALTH, NUTRITION, AND LIVELIHOOD BENEFITS OF DAIRY PRODUCTION}

Milk and dairy products are a source of essential nutrients, especially for children and pregnant woman. Milk contains protein and calcium and is a good source of vitamin $\mathrm{B}_{12}$, thiamine, and riboflavin. Along with other animal-source foods, milk consumption has been found to improve anthropometric indices and cognitive function in children and to reduce nutritional deficiencies (Dror and Allen, 2011; Grace et al., 2017a).

Diets of young children in developing countries are often restricted to cereals and legumes; however, the inclusion of animal-source foods is necessary to optimize children's nutritional needs. There is convincing evidence that dairy protein improves linear growth even in well-nourished children; evidence is strongest for school-age children (Grenov and Michaelsen, 2018). A review on the importance of milk and dairy in children's diets concluded that its consumption is associated with improved bone development (Dror and Allen, 2011) in both wealthier and poorer populations.

Milk is widely consumed in low- and middle-income countries (LMIC), although this is strongly influenced by culture and geography. It is especially important in South Asia and North Africa as well as the East African highlands (Headey et al., 2017). Production of dairy may be easier to intensify and scale up than production of meat, and predictive models show how dairy products are among the leaders in the livestock revolution (Figure 1).

Dairy production as well as consumption contributes to livelihoods. In many LMIC, dairy value chains are a primary source of income for rural populations. Money earned from producing, processing, and selling milk can be used to improve quality of life. In many cultures, milk is one of the few resources that is under the control of women, both as food for the family and a source of earnings from processing and sale. For example, a food safety project assessed gender roles in 20 animalsource food value chains (Grace et al., 2015). Overall, women were more involved in dairy and fish and less involved in meat and game value chains. In West Africa, men fed cattle and milked cows, but in Kenya this was women's responsibility. In all studies women were responsible for processing (e.g., fermentation). In 3 of the studies where traditional dairying predominated, women were in charge of marketing. In urban Cote d'Ivoire, where dairying was novel, men had taken over marketing. Entrepreneurship can also empower women, and several studies have shown positive links between women's empowerment and children's health. This fact is of great importance in the link between dairy production, consumption, and nutrition because women are generally in charge of household nutrition, are the main custodians of food cultures, and have been shown to prioritize food expenditures more than men do (Grace et al., 2015).

Moreover, whereas poultry, pig, and fish production have large economies of scale, making it hard for smallholders to compete with industrial production, dairying is much more land and labor intensive, so it is more likely to remain a viable option for smaller farmers for longer, thus supporting livelihoods in LMIC. Dairy production can also be environmentally sustainable, especially when cattle diets rely on crop by-products and non-commodity feeds such as pastures and forages (Britt et al., 2018). A comparative study found that dairy-based diets ranked more highly than vegan-, egg-, and omnivore-based diets in terms of feeding the greatest number of people while adhering to recommended agronomic practices for various classes of lands (Peters et al., 2016). Manure is also an important source of organic matter in soil.

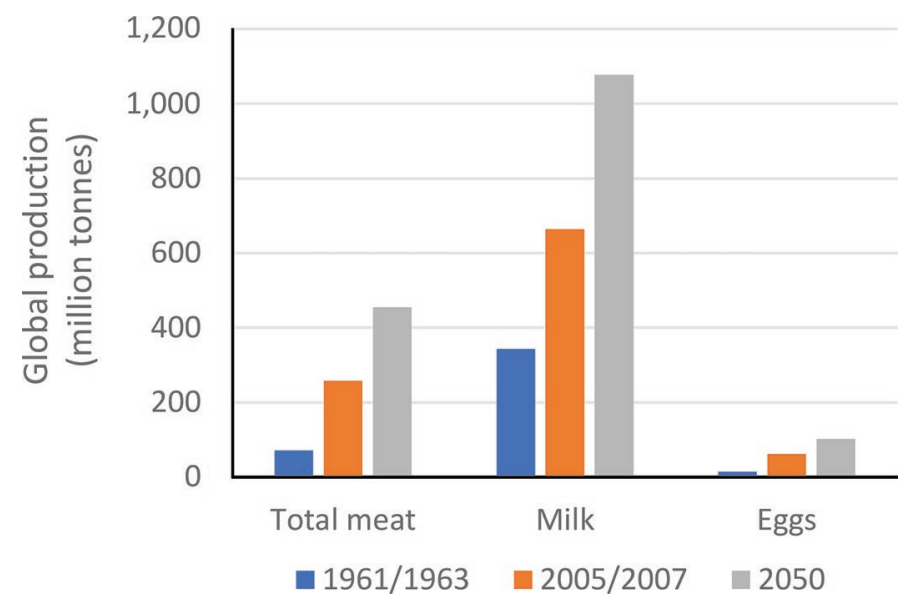

Figure 1. Global production of some livestock-derived foods (1961-2050). Data from Alexandratos and Bruinsma (2012). 
Despite these benefits of dairy production and consumption, several important risks are associated with milkborne contaminants. These are discussed in the next sections.

\section{HEALTH RISKS OF MILK}

This section summarizes concepts that are important for understanding milk and health risks but that are often confused: (1) the difference between safety and quality, (2) hazards associated with consumption of milk, and (3) the difference between hazard and risk.

Food safety refers to the absence of substances, whether natural or artificial, that may make food injurious to the health of the consumer. Quality includes all other attributes that influence a product's value to the consumer. This includes negative attributes such as spoilage, adulteration, contamination with filth, discoloration, off-odors, and other nonhazardous substances as well as positive attributes such as the nutritional quality attributes (e.g., fat, protein), origin, color, flavor, texture, and processing method of the food. Adulteration always reduces the value of the product to the consumer (a measure of quality) and, depending on the type of adulteration, may introduce health hazards or reduce other aspects of quality, such as nutritional content (Spink et al., 2017).

In food safety terminology, a hazard is something that can harm human health. A wide range of hazards can be present in food.

- Biological hazards in the context of food are infectious organisms that can infect people or produce toxins that harm health. These include microorganisms (including viruses, bacteria, fungi, and protozoa) as well as larger organisms such as helminths. Studies estimate that biological hazards cause foodborne illness in between 10 and $30 \%$ of the population every year (Gkogka et al., 2011; Scallan et al., 2011; Havelaar et al., 2015).

- Chemical hazards include artificial industrial chemicals (e.g., pesticides or disinfectants) and natural chemicals (e.g., toxic metals such as lead) that are injurious to health. Most consider toxins produced by fungi (mycotoxins) to be chemical hazards. The health effects of foodborne chemicals and toxins can be serious and include illnesses ranging from mortality to cancer to immune system impairment (Wu et al., 2014; Havelaar et al., 2015; Gibb et al., 2019).

- Allergenic hazards are proteins that are naturally present in milk or other foodstuffs that can lead to an adverse immune response in some people.
Allergies usually start early in life and can cause gastrointestinal, skin, or respiratory symptoms. In countries with good data, milk allergies affect 0.25 to $5 \%$ of the population (Motala and Fiocchi, 2011). Milk allergies are believed to be less common, but increasing, in LMIC.

- Physical hazards include stones and fragments of metal or glass. They are not usually associated with sickness or death but may be reasons for recall and have considerable economic consequences.

Milk is an excellent substrate for bacterial growth and microbial survival at permissive temperatures (Hassan and Frank, 2011). Harmful bacteria may originate from the animal, the environment, milking equipment, or the milk handlers or be introduced with an adulterant such as contaminated water. Chemical contaminants may enter the milk through the feed or veterinary treatments of the animal or through later accidental or deliberate contamination.

Several chronic diseases have also been associated with milk consumption (especially at high levels), linking dairy consumption to cancer, cardiovascular disease, and obesity, which may be linked to milk fat or specific dairy proteins. Other studies show the opposite or no relation between dairy consumption and these diseases (Larsson et al., 2015; Mozaffarian, 2019).

A health problem unambiguously linked to milk consumption is lactose intolerance. (Food intolerances are nonimmunological adverse reactions to food as the result of pharmacological effects, non-celiac gluten sensitivity, or enzyme or transport defects.) Lactose is a sugar that is naturally present in milk that all infants can digest because they produce lactase. However, lactase production does not persist in many people. Undigested lactose is fermented by bacteria in the colon, resulting in mild to moderate gastrointestinal symptoms such as diarrhea and pain. About $70 \%$ of the world's population is lactose intolerant (Heine et al., 2017). The public health burden from deficiencies attributable to lactose intolerance has not been established, but the condition is mild and can be managed.

However, dairy production can affect health through other pathways (McDaniel et al., 2014). Cattle can be reservoirs for zoonotic diseases, which can be transmitted by direct contact or by environments contaminated with animal manure. For example, brucellosis is often acquired by handling aborted material (although it is also transmitted by milk), and campylobacteriosis may result from environment contamination in rural areas or contamination of the milk by bovine feces. Antimicrobial residues are chemical hazards commonly found in food, but their main health effects are through fostering pathogens resistant to antimicrobial treatment, 
not through direct consumption of milk. Cattle may also cause acute injuries or be associated with chronic trauma (e.g., arthritis associated with repetitive joint stress from working in dairies).

Hazards, as discussed above, are important because they have the potential to cause sickness and, in some cases, even death. However, the mere presence of a hazard in milk does not mean that it is necessarily going to harm a person's health; "the dose makes the poison" (Grandjean, 2016). To understand the implication of hazards for human health, we need to assess risk. In food safety, risk is a combination of the severity of harm to human health and the probability of its occurrence. This has several important implications. First, just because a hazard is found in milk does not necessarily mean it will cause illness or death; this implies that regulation and control should be based on risks and not hazards. Second, substances may be harmless or even beneficial in small amounts but cause problems if they are consumed in large amounts. Third, for many chemical substances there may be a threshold below which a hazard is unlikely or unable to cause harm.

\section{MILKBORNE DISEASE IN LMIC}

Dairy products were an important cause of disease in the 19th century in now-developed countries. Milk became safer as the result of widespread pasteurization and improvements in hygiene and disease eradication schemes (especially addressing tuberculosis, brucellosis, typhoid, paratyphoid, and food poisoning) in combination with testing, regulation, and advances in hygiene. In developed countries, almost all milk is now pasteurized and standards for dairy products are effectively maintained. Consumption of unpasteurized milk continues to be associated with foodborne disease (FBD) outbreaks, even in developed nations where a small proportion of consumers choose to drink raw milk (Costard et al., 2017). A small number of studies from LMIC have also implicated dairy as a cause of FBD. For example, in India dairy products have been implicated as important in several studies (Abraham et al., 1997; Sudershan et al., 2014; Khare et al., 2018).

Until recently, there was very little solid evidence of the health and economic burden of FBD, let alone milkborne disease, in LMIC. However, we can triangulate different approaches to better understand the health burden. In the rest of this section, we summarize the methods and findings of 6 important approaches, including (1) global burden of disease studies, especially the World Health Organization study on the burden of FBD; (2) official records on FBD outbreaks; (3) historical evidence from high-income countries (HIC); (4) studies on hazard presence and prevalence in milk; (5) assessments of the health risk posed by different hazards; and (6) studies on compliance with standards.

\section{Global Burden Studies: WHO Foodborne Disease Burden Epidemiology Reference Group and Institute of Health Metrics and Evaluation}

For many years, information on health effects of FBD was not available or was limited to selected HIC, such as the United States, Canada, and the Netherlands (Scallan et al., 2011; Thomas et al., 2013; Havelaar et al., 2015). To address this gap, an initiative was launched by the WHO Foodborne Disease Burden Epidemiology Reference Group (FERG) in 2006. Based on almost a decade of work by various experts and expert panel groups, the results were published in December 2015. The FERG used systematic reviews and meta-analysis to estimate the global incidence of disease, deaths, and disease burden (disability-adjusted life years, DALY; see, e.g., Devleesschauwer et al., 2014). They then used a structured elicitation of scientific judgment that consisted of expert panels combined with various mathematical models to estimate the proportion of FBD. They found that 31 FBD hazards (both biological and chemical hazards) globally accounted for around 600 million cases of FBD and 420,000 deaths, imposing a burden of around 33 million DALY each year (Havelaar et al., 2015). More recently, the FERG reported on the burden of disease due to 4 heavy metal chemical hazards; this was an additional 9 million DALY globally. The FERG estimates have been broken down by subregion based on the 6 WHO regions and further subdivided based on child and adult mortality. It was found that the largest share of FBD burden occurred in LMIC, where particularly children under $5 \mathrm{yr}$ of age bear a large share of the burden (Havelaar et al., 2015).

A follow-up study by the FERG attempted to assess the contribution of animal-source foods. The study involved 13 out of 31 hazards that were included in the global burden of FBD estimates and can be associated with animal-source foods. These hazards accounted for just over $40 \%$ of the total foodborne DALY. The proportion of FBD attributable to 8 different animalsource food groups was estimated by structured expert elicitation (Hoffmann et al., 2017). By combining these attribution estimates with the burden estimates, dairy was estimated to be responsible for 20 DALY per 100,000 people in 2010 ( $\mathrm{Li}$ et al., 2019). This corresponded to around $12 \%$ of the FBD burden associated with animal-source food and $4 \%$ of the overall FBD burden. The importance of dairy products and the pathogens causing the highest burden varied considerably by region, as shown in Figure 2. Globally, non- 
typhoidal Salmonella enterica, Campylobacter spp., and Mycobacterium bovis are the most important hazards in dairy products, whereas Brucella spp. are of particular concern in the Eastern Mediterranean region. Shiga toxin-producing Escherichia coli, Cryptosporidium spp., and Toxoplasma gondii caused a relatively low burden through dairy.

The regional classification of the WHO does not completely correspond to World Bank income categories. For example, Cuba is an LMIC but along with Canada and the United States (both HIC) constitutes the region AMR A. However, the regions AMR A, EUR A, and WPR A comprise mainly HIC, and the other 11 regions comprise mainly LMIC. This allows us to make an approximate estimate of the health burden of milkborne disease in LMIC.

The FERG estimates may underestimate the true burden of FBD, including diseases related to dairy. Only a limited number of pathogens for which cattle can be reservoirs and that can be transmitted by dairy products were assessed due to a lack of reliable data (see Table 1). Furthermore, dairy products can be a vehicle for non-zoonotic pathogens. For example, ice cream from unreliable sources is frequently contaminated with hepatitis A virus, and dairy products can be a vehicle for listeriosis. Although the FBD burden of these hazards has been quantified by FERG, it has not been attributed to dairy or other food products. Not all health outcomes from FBD could be included in the estimates, again because of a lack of data. For example, there is increasing evidence that asymptomatic infections with enteric pathogens, including those that can be transmitted by dairy, are associated with malnutrition, in particular stunting, which affects 155 million children globally (Rogawski et al., 2018). Also, FBD occurring in highly vulnerable populations, such as people with HIV or AIDS, were not included in the FERG estimates because they were already included in the burden of HIV infection. Nevertheless, these FBD would be prevented by improved food safety management.

Other sources of global disease burden estimates include the WHO Global Health Estimates, the WHO Childhood Epidemiology Reference Group, and the Institute of Health Metrics and Evaluation. A direct comparison of FERG results with those sources is difficult because of differences in methods and assumptions that may have an important effect on burden estimates, but the results are reasonably consistent. Table 2 shows estimates of the disease burden of milkborne hazards considered by different studies. Note that only the FERG study has estimated, for a limited number of

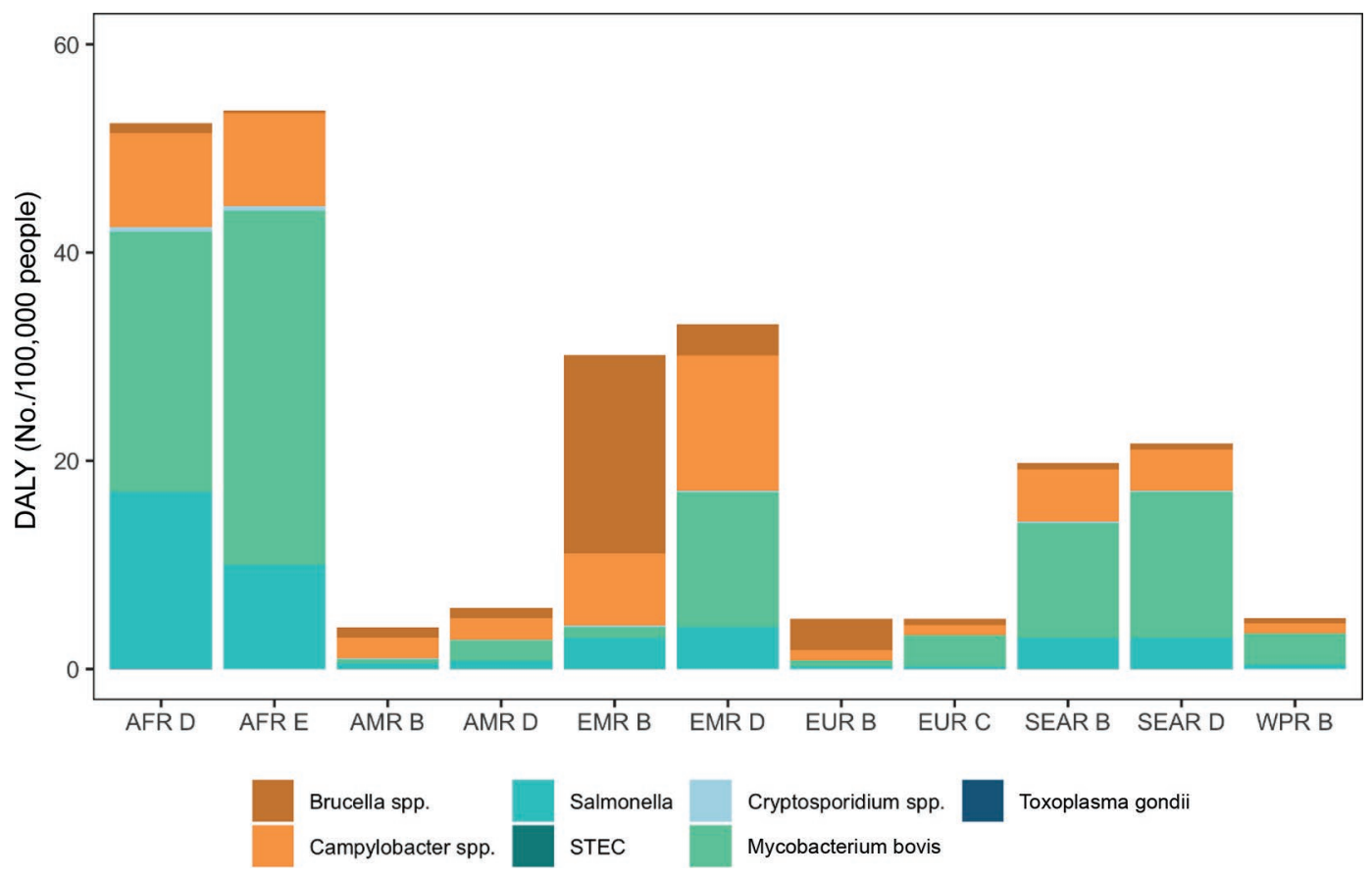

Figure 2. Global burden of disease from dairy products by region and some important hazards. DALY = disability-adjusted life years; STEC = Shiga toxin-producing Escherichia coli. The x-axis codes refer to WHO regions: AFR $=$ Africa; AMR = the Americas; EMR = Eastern Mediterranean; EUR = Europe; SEAR = South-East Asia; and WPR = Western Pacific. Regions are further subdivided on the basis of mortality: $\mathrm{B}=$ low child mortality and very low adult mortality; $\mathrm{C}=$ low child mortality and high adult mortality; $\mathrm{D}=$ high child and adult mortality; $\mathrm{E}=$ high child and very high adult mortality. For more details, see Li et al., (2019). 


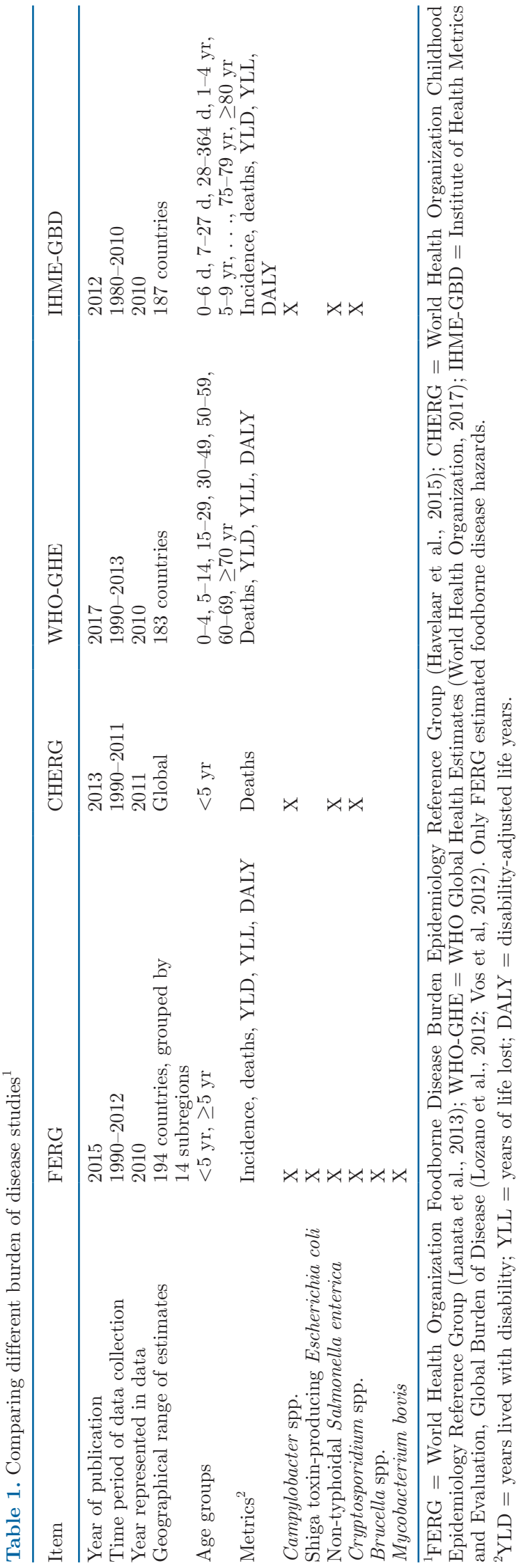

hazards, how much of that burden is attributable to dairy products.

\section{Official Records on Outbreaks}

One must be cautious when extrapolating from outbreak data. Most cases of FBD do not occur as outbreaks but rather as sporadic cases. Moreover, in many countries there is no requirement to report FBD. Even if there is a requirement, the reporting system may not be adequate, resulting in massive underreporting. For example, in Gansu in China, there were an estimated 30 million cases of acute gastrointestinal disease, but only 400 cases were reported to the official system (Sang et al., 2014). Even when outbreaks are reported, the investigations may not be comprehensive. Nonetheless, data from outbreak investigations may be the most readily available and reliable source of information in some situations (Pires et al., 2014).

In HIC, dairy is responsible for around 1 to $6 \%$ of reported outbreaks (Claeys et al., 2013). However, these do not include dairy products incorporated into other foods (e.g., custards). When modeling is used to attribute the ingredients of complex foods, the burden of milkborne diseases is higher. Using data from outbreak-associated illnesses for 1998 to 2008, Painter et al. (2009) estimated annual US foodborne illnesses, hospitalizations, and deaths attributable to each of 17 food commodities. Dairy was responsible for $13.8 \%$ of all illnesses, $16.2 \%$ of hospitalizations, and $9.7 \%$ of deaths. Pires et al. (2012) analyzed official records of FBD outbreaks in the Caribbean and Latin America from 1993 to 2010 using a similar method. Overall, animal-source food was responsible for $85 \%$ of the foodassociated outbreaks and dairy was responsible for $20 \%$ of the total outbreaks.

In HIC there is currently widespread pasteurization, animal disease control, hygienic milking, testing, and cold chains, which are lacking in many LMIC. This would imply that dairy is an important contributor to FBD LMIC. Interestingly, in the United States, drinking raw millk was associated with 840 times as many illnesses as drinking heat-treated milk (Costard et al., 2017). On the other hand, milk consumption is absolutely and relatively higher in HIC, which might imply that milk would contribute less to FBD in LMIC. Latin America and the Caribbean are more representative of LMIC. Here, the contribution of dairy to FBD declined 14-fold over the 2 decades (1990s and 2000s; Pires et al., 2012). This was associated with rapid growth and formalization of the dairy sector, which has not been seen in most LMIC, where smallholder and informal production continue to predominate. 


\section{Historical Importance of Dairy Products in FBD}

Somewhat analogous to the situation in LMIC today, the 19th century saw many European and North American countries undergoing rapid urbanization, industrialization, and economic growth. This was associated with a decline in the wholesomeness of food as production shifted closer to cities, where conditions were often unhygienic and opportunities for food fraud increased (Grace et al., 2008a). Milk was a major cause of FBD, especially for infants. In the 19th century, typhoid was the major cause of FBD, followed by streptococcal disease and diphtheria, which were mainly attributed to milk (Currier and Widness, 2018), whereas in the mid 20th century, brucellosis and tuberculosis were important. In 1938, milkborne outbreaks accounted for $25 \%$ of all disease outbreaks from contaminated food and water in the United States (FDA, 2011). Introduction of widespread pasteurization of milk has dramtically reduced this disease burden. The pre-pasteurization era in developed countries can be considered analogous to the current situation in many LMIC, and major health benefits can be expected from more broadly adopting pasteruization or other effective processing methods.

\section{Presence and Prevalence of Hazards in Milk}

The isolation of disease-causing bacteria in raw milk is another indicator of potential risk to human health. As mentioned, the presence of a hazard in food is often a poor guide to the risk to human health. Storage, processing, amount consumed, diet, co-infection, and host factors may contribute to the amplification, reduction, or elimination of risk associated with hazards present in milk. Information on the presence and prevalence of hazards in milk is also useful as benchmarks and in prioritization for subsequent risk assessment. Systematic data from developing countries are largely lacking, but many individual studies have been conducted, and these often find hazards in milk.

Table 3 sets out hazards of concern, their potential health effects in LMIC, how they enter milk, and the limited evidence for their importance in LMIC (ordinal scale: major, moderate, minor, very low, possible). For milk contamination route, 4 pathways are considered: animal (direct passage from the blood into the milk), udder (udder infection), feces (contamination of milk with animal feces during milking or on-farm storage), and environment (e.g., air, dirty equipment, contami-

Table 2. Quantitative microbial risk assessments on dairy products in low- and middle-income countries

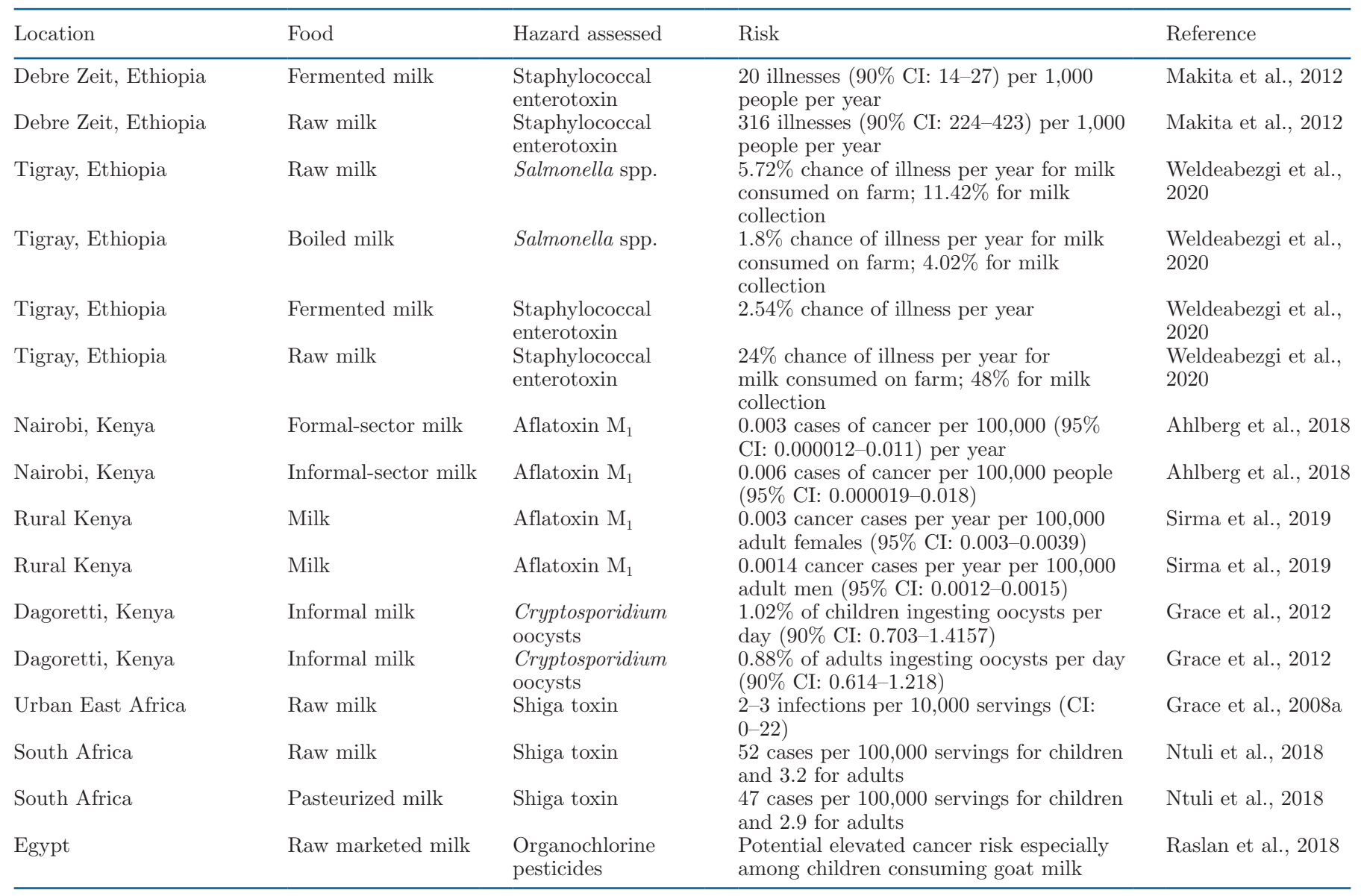


nated water, milker, milk handler). The authors used largely subjective criteria to assess health importance based on their personal experience of working in LMIC. The category "possible" indicates that the role of milk consumption in disease transmission is still ambiguous.

\section{Risk Assessments}

Quantitative risk assessment is a predictive or inductive method that assesses risk by combining exposure, dose-response, and severity of health effects. It has been adopted by the Codex Alimentarius Commission and underpins trade in foods and livestock. By taking the core concepts of risk analysis and combining them with proven development analytic methods such as participatory rural appraisal and gender analysis, an approach emerged that could be successfully applied to the food safety challenges in developing countries (Grace et al., 2008b). The approach was subsequently used in Tanzania, Uganda, Vietnam, and elsewhere, and its strengths and weaknesses as well as the recommendations generated were captured in peer-reviewed publications (Häsler et al., 2018; Nguyen-Viet et al., 2019; Roesel et al., 2019).

This approach, involving rapid qualitative and quantitative studies on hazards and risk, has been applied to several dairyborne diseases; many of the studies were conducted by scientists at the International Livestock Research Institute in Kenya. Table 3 summarizes key findings.

These risk assessments confirm that aflatoxins in milk have lesser known health effects than biological hazards. The risk assessments also suggest that processing milk (boiling, fermentation, or pasteurizing) reduces but does not eliminate risk. Some assessments find relatively high risks for single pathogens, implying that milkborne disease may be more common than the estimates from the FERG. However, bottom-up quantitative risk assessments tend to produce higher estimates of risk than top-down epidemiologic methods.

\section{Studies on Compliance}

Public food safety standards are enacted to protect consumers' health by ensuring safe food and to eliminate fraudulent practices. Food legislation has typically been designed to set a minimum standard (or agreed level) of safety and quality that society finds acceptable. Historically, many food standards were hazard-based, specifying that a hazard should be absent according to a specified testing method. More recently, standards often seek to incorporate a risk perspective but may also take a precautionary approach. Such standards have been developed mainly in HIC. In the absence of resources and data to define standards that are appropriate for the local context, LMIC often copy standards from HIC. Compliance with standards is only a proxy for food safety, as food may not comply and yet pose little risk and vice versa. In LMIC, it is very common for a substantial proportion of food and feed to fail to comply with standards adopted from HIC, which may cause considerable concern among governments and consumers. Table 4 summarizes some studies on dairy products in Kenya that are not atypical for other LMIC.

It has been said that when $5 \%$ of milk fails to meet standards, there is a problem with milk, but when $90 \%$ fails, there may be a problem with standards. The high level of noncompliance, the many different regulations between and sometimes within countries, and the proliferation of regulations in advance of the ability to enforce them raise concerns, and there is an urgent need to develop approaches to develop standards for LMIC that are locally appropriate and focus on the most important health risks rather than hazards that are easily measured. There may also be severe tradeoffs between compliance with food safety regulations and other societal objectives such as food and nutrition security that raise difficult questions. For example, one study in Kenya found that if aflatoxin standards for maize and sorghum were strictly enforced, around 9,000,000 Kenyans would be deprived of the bulk of their diet and about 3,400,000 Kenyans would be deprived of milk (Sirma et al., 2018).

\section{Appropriate Dairy Safety Regulation: Aflatoxin $M_{1}$ as an Example}

Discovered in 1960, aflatoxins - toxins produced by certain Aspergillus fungi primarily in maize and nutshave long been known to cause liver cancer in humans and diverse other adverse effects in humans and animals, including acute toxicity, growth impairment, and immune system dysfunction (Kensler et al., 2011; Khlangwiset et al., 2011; Wu, 2015). Lactating animals that consume aflatoxin $\mathrm{B}_{1}\left(\mathbf{A} \mathbf{F} \mathbf{B}_{1}\right.$; the most prevalent and toxic of the aflatoxins in maize and nuts) in their feed secrete a metabolite of that toxin in their milk, referred as aflatoxin $\mathrm{M}_{1}\left(\mathbf{A F M}_{1}\right.$; Kensler et al., 2011). Although the human health risks of $\mathrm{AFM}_{1}$ are far from well established, regulatory agencies have set standards for $\mathrm{AFM}_{1}$ in milk and dairy products simply based on taking the existing $\mathrm{AFB}_{1}$ or total aflatoxin standard (in a given nation) and dividing by a factor that roughly estimates how much $\mathrm{AFM}_{1}$ is produced in milk when parent aflatoxin is present in dairy animals' diets $(\mathrm{Wu}$ and Saha Turna, 2019). Implicit in this calculation is 
Table 3. Hazards found in milk and dairy products in low- and middle-income countries (LMIC) ${ }^{1}$

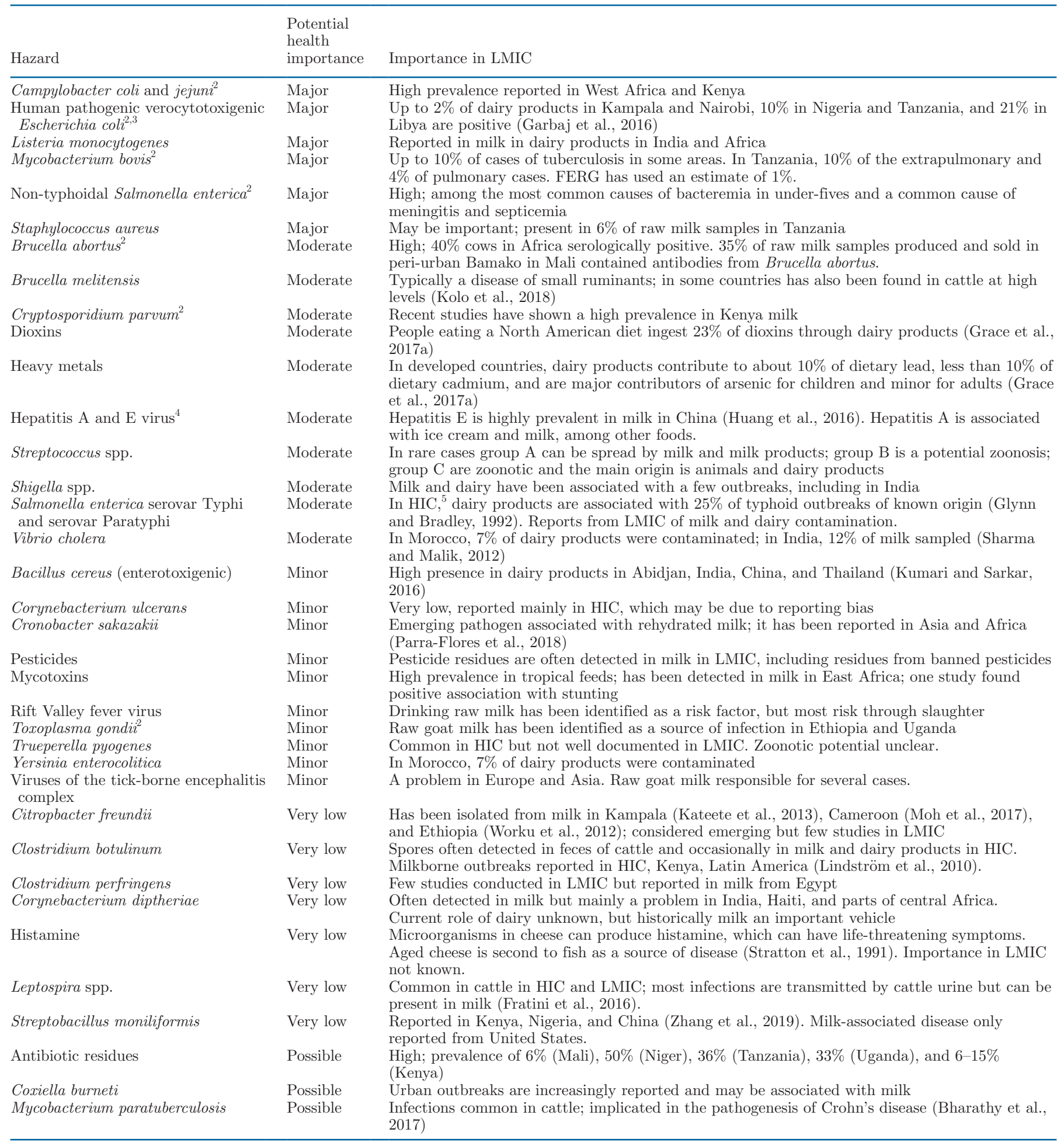

\footnotetext{
${ }^{1}$ Table adapted and updated from Grace et al. (2007); references given in that paper are not repeated here.

${ }^{2}$ Considered by the World Health Organization Foodborne Disease Burden Epidemiology Reference Group (FERG) in attributing foodborne disease to milk and other animal-source foods.

${ }^{3}$ Only certain strains of E. coli that are transferred by cattle, which contain a combination of virulence factors and that are pathogenic to humans. Strains of the serotype O157:H7 are the most frequently reported, but strains of other serotypes can result in human cases as well (e.g., O26, O91, O103, O111, O121 and O145).

${ }^{4}$ Only genotype 4 of hepatitis $\mathrm{E}$ has been found in cattle; genotypes 3 and 4 are zoonotic, but the main host is pigs.

${ }^{5} \mathrm{HIC}=$ high-income countries.
} 
that $\mathrm{AFM}_{1}$ is as toxic as $\mathrm{AFB}_{1}$, which no evidence has shown. Indeed, existing studies suggest that $\mathrm{AFM}_{1}$ toxicity and carcinogenicity are far less than that of $\mathrm{AFB}_{1}$ (EFSA, 2020). Unfortunately, many policymakers worldwide have assumed that $\mathrm{AFM}_{1}$ is just as toxic as $\mathrm{AFB}_{1}$. Consequently, newspaper headlines have warned people to avoid drinking locally produced milk; this has set back early childhood milk-based nutrition interventions and paralyzed the dairy industry in Ethiopia, for example. Similar headlines have been published in other countries such as Kenya. As ever more nations suffer market losses due to $\mathrm{AFM}_{1}$ in dairy products exceeding regulated levels, especially the stringent EU limit of $0.05 \mu \mathrm{g} / \mathrm{kg}$, there is a need to better characterize the true human health risk of this chemical in our daily diets in order to inform policy decision making and public health officials on the true nature of the risk.

For the purposes of sensible policymaking on food safety that does not cause excessive economic loss (Wu, 2004), there is a critical need to compare both the toxicity of and the exposure to $\mathrm{AFM}_{1}$ with $\mathrm{AFB}_{1}$ to be able to judge relative risks. It is also important to understand whether $\mathrm{AFM}_{1}$, like $\mathrm{AFB}_{1}$, has a synergistic interaction with hepatitis $\mathrm{B}$ virus infection to increase liver cancer risk and to compare exposure patterns of these 2 chemicals. In multiple LMIC, high $\mathrm{AFM}_{1}$ contamination levels have been detected in milk (as reviewed in Wu and Saha Turna, 2019). This is likely be- cause maize grain and oil seed cakes are used in animal feed, and these can have extremely high aflatoxin levels (Liu and Wu, 2010; Liverpool-Tasie et al., 2019). For instance, studies in Ethiopia and Rwanda have identified oil seed cakes as the main source of $\mathrm{AFB}_{1}$ in feed (Gizachew et al., 2016; Nishimwe et al., 2019). There is a need to continue to identify which feed components contribute most to $\mathrm{AFB}_{1}$ exposure of cattle and how to control this contamination.

\section{ECONOMIC BURDEN OF DAIRYBORNE DISEASE}

Foodborne diseases are associated with a wide range of economic costs. These can be divided into (1) the harm caused by the disease (e.g., lost productivity from illness), (2) the cost of response (e.g., treatment, food recalls), and (3) cost of prevention (e.g., food safety governance, risk-reducing practices). Alternatively, costs may be allocated to different actors (consumer, health care, agro-food industry, government; McLinden et al., 2014). Zoonotic diseases often exert additional burdens on the livestock sector, and it is important that estimates of costs cover multiple sectors. Costs associated with market access and trade are not further discussed in this paper.

Valuation of health benefits is now an established tool for identifying the highest priorities for public health investments. Although valuation methods have recognized limitations, they can provide insights into

Table 4. Dairy products failing to comply with standards in Kenya ${ }^{1}$

\begin{tabular}{|c|c|c|c|}
\hline Site & Sample & Failure to comply with standards ${ }^{2}$ & Reference \\
\hline Lamu County & $\begin{array}{l}\text { Milk vendor } \\
\text { (informal) }\end{array}$ & $\begin{array}{l}25 \% \text { unacceptable composition } \\
18 \% \text { were outside limit for AM residues } \\
29 \% \text { failed composition or AM residue }\end{array}$ & Ondieki et al., 2017 \\
\hline Nakuru & Peri-urban milk & $43 \%$ were outside limit for sulphonimides & Orwa et al., 2017 \\
\hline Nanyukii and Isiolo & Camel milk & $75 \%$ were outside microbiological limits & Kaindi et al., 2011 \\
\hline Not reported & Camel milk & $\begin{array}{l}92 \% \text { exceeded TVC } \\
100 \% \text { exceeded coliform }\end{array}$ & Matofari et al., 2013 \\
\hline Kisumu and Eldoret & $\begin{array}{l}\text { Informal and } \\
\text { pasteurized }\end{array}$ & $\begin{array}{l}43 \% \text { of informal milk and } 71 \% \text { of formal milk did not meet } \\
\text { total bacterial count standards }\end{array}$ & Alonso et al., 2018 \\
\hline Nandi & $\begin{array}{l}\text { Raw and boiled } \\
\text { vended }\end{array}$ & $60 \%$ of raw and boiled milk were outside coliform & Ogot et al., 2015 \\
\hline Nairobi & $\begin{array}{l}\text { Raw and } \\
\text { pasteurized }\end{array}$ & $\begin{array}{l}53 \% \text { exceeded acidity standards } \\
96 \% \text { of raw and } 21 \% \text { of pasteurized exceeded TVC } \\
78 \% \text { of raw and } 5 \% \text { of pasteurized exceeded coliform }\end{array}$ & Wanjala, 2017 \\
\hline Kiambu & Shop milk & $\begin{array}{l}64 \% \text { of milk exceeded coliform } \\
54 \% \text { exceeded total plate count } \\
27 \% \text { exceeded adulteration (compositional) } \\
0 \% \text { exceeded AM residue } \\
0 \% \text { with hydrogen peroxide }\end{array}$ & Orregård, 2013 \\
\hline Nairobi & Informal & $66 \%$ of samples above aflatoxin limits & Kuboka et al., 2019 \\
\hline 5 Urban centers & Formal & $31 \%$ exceeded the WHO/FAO levels for aflatoxin & $\begin{array}{l}\text { Kang'ethe and Lang'a, } \\
2009\end{array}$ \\
\hline Nairobi & Informal & $55 \%$ were over EU maximum for aflatoxin & Kirino et al., 2016 \\
\hline Bomet County & Formal & No aflatoxin in processed milk or UHT & Langat et al., 2016 \\
\hline
\end{tabular}

${ }^{1}$ Adapted from Harcourt-Brown et al. (2018).

${ }^{2} \mathrm{AM}=$ antimicrobial residues; $\mathrm{TVC}=$ total viable count; WHO/FAO = World Health Organization and Food and Agriculture Organization of the United Nations. 
the economic cost of illness and the potential value of reducing the burden of illness. It is important to understand the basis for such estimates, as they can be misinterpreted. For example, estimates of the economic burden of FBD in the United States vary from $\$ 14$ billion to $\$ 77$ billion due to differences in methodology and pathogen coverage (Hoffmann and Anekwe, 2013).

Gross national income per capita can be used as a measure of lost productivity. Intuitively, for each year lost to illness, disability, or premature death, the economy loses the economic output associated with that year. Using this approach, a recent paper by the World Bank estimated the cost of FBD at US\$95.2 billion for LMIC in 2016 (Figure 3; Jaffee et al., 2019). Using the FERG estimates that $4 \%$ of the FBD burden in term of DALY is due to milk and combining it with the approach used in the aforementioned World Bank paper, this would imply that the economic cost is around US $\$ 4$ billion, which likely is an underestimate.

\section{REDUCING THE HEALTH AND ECONOMIC BURDEN OF DAIRYBORNE DISEASE}

There have been many approaches to improving milk safety and quality in LMIC. Some of the most important, summarized in Grace (2017), are as follows:
- Training farmers in hygienic milk production

- Organizing farmers into dairy co-operatives that can better control quality

- Linking farmers to a variety of services through dairy hubs to improve milk production

- Supporting the formal sector processing and retail

- Training and legitimization of the informal sector

- Improving consumer awareness on milk handling and safety

- Technologies that improve health of cattle, such as mastitis detection and treatment

- Technologies that help preserve milk, such as lactoperoxidase, heating, and chilling

- Technologies that improve handling of milk, such as wide-necked milk cans

- Technologies that improve access to information and services, such as obtaining information or making payments using mobile phones

- Enforcing food safety legislation

Milk safety can also be improved as a by-product of more general development interventions such as improving road, water, and electricity infrastructure and better primary and secondary education. In most countries these broad-based interventions have been associated with improvement in a wide range of health outcomes.

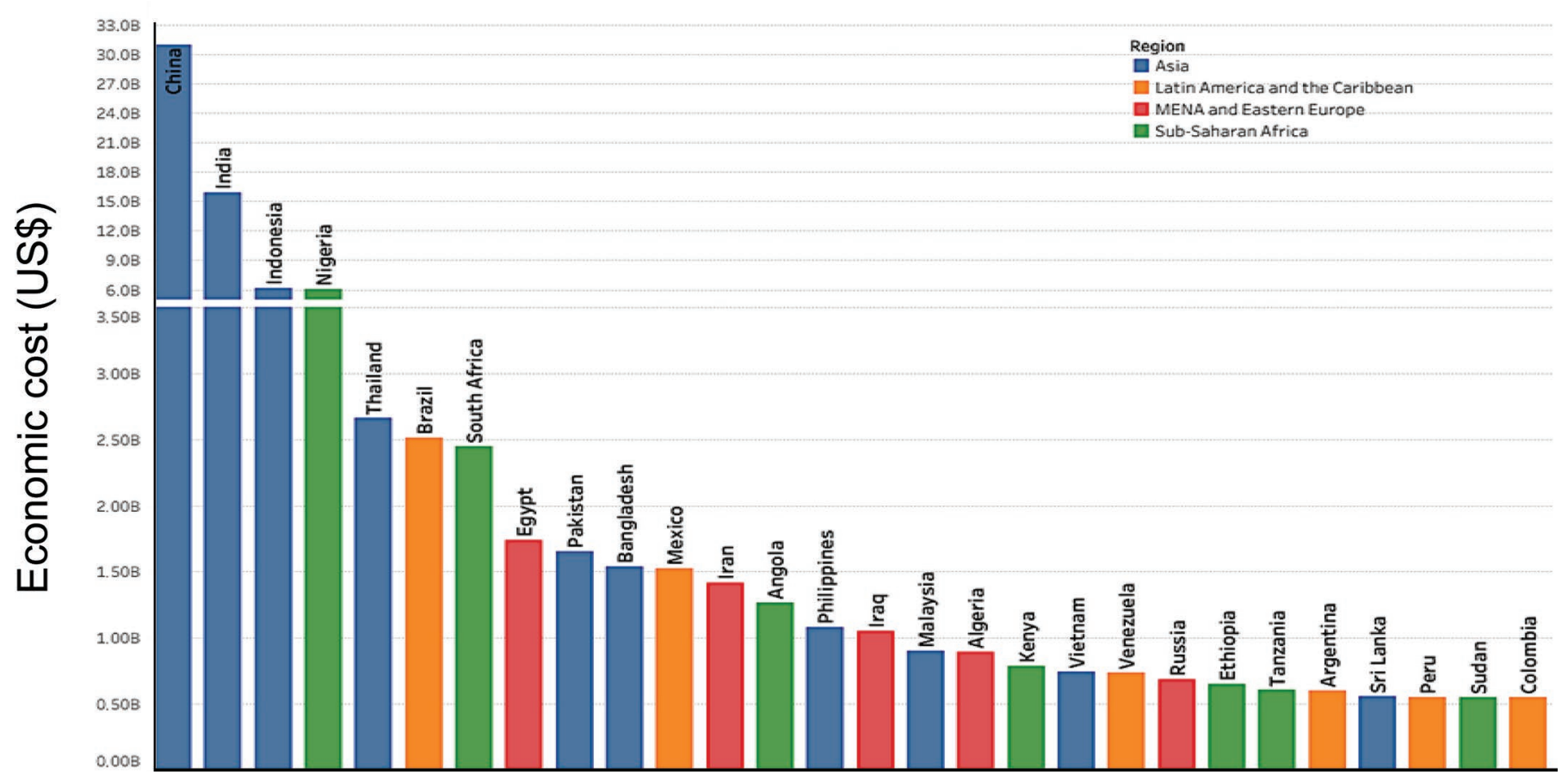

Figure 3. Economic cost per year of foodborne disease in low- and middle-income countries (Jaffee et al., 2019). MENA = Middle East and North Africa. 
Although many of the more specific approaches have had some success, major problems with milk safety persist in many countries (Grace et al., 2007). One key aspect is that most milk is still obtained from informal markets. For example, in Tanzania more than $90 \%$ of marketed milk goes through the informal sector (Kilelu et al., 2017), and in more urbanized Kenya $86 \%$ of milk is informal (Kaitibie et al., 2010). Even in India, the world's top milk producer and which has heavily invested in co-operatives, $83 \%$ of the milk is consumed in the unorganized sector (DAHD, 2020). These markets are favored by consumers because, for example, milk is cheaper than that sold in the formal sector, there is more flexibility in the quantity sold, outlets are closer to the consumer's house and some hawkers even deliver to the doorstep, and consumers prefer the taste of unprocessed milk. The lower price of informal-sector milk is especially important to poor consumers. A recent study in Nairobi found that poor households spend 38\% of their total food expenditure on livestock products and fish, and of that, $37 \%$ was spent on milk and dairy product. In this context, increasing the price of milk could have adverse effects on nutrition (Cornelsen et al., 2016).

Working with the informal sector is likely to be necessary if widespread and rapid improvements in food safety and quality are desired. In Kenya in the early 2000s, a training and certification scheme was designed and launched to improve quality and safety in informal dairy markets by improving the practices of traders and at the same time supporting the livelihoods of dairy value chain actors. The scheme was taken up by a large proportion of eligible traders (with project support). They received capacity-building training in hygienic milk handling and business practices and at the end of training could apply for a certificate from the Kenya Dairy Board that entitled them to legally sell milk. Participant tests before and after training showed that trader knowledge and practices improved, and microbiological tests showed that there was a substantial and significant decrease in unsafe milk. A later economic evaluation found an important reduction in transaction costs attributable to less harassment by authorities, less confiscated equipment, and fewer bribes paid but also fewer losses of milk due to spoilage (Kaitibie et al., 2010).

There is also much scope to improve milk safety in high-risk communities. Especially relevant are pastoralists who often have high dietary dependence on milk yet risky practices such as drinking raw milk. In these communities, women often play a key role and must be engaged (FAO and CARE, 2019).

\section{CONCLUSIONS}

This paper draws on the literature in order to assess the health and economic burden of milk and dairy products in LMIC and to identify the priority hazards. Much is unknown about the disease burden of milkborne disease. The best estimates come from the FERG study, which suggests that milk and dairy are responsible for $4 \%$ of the overall global FBD burden, corresponding to 20 DALY per 100,000 people in 2010. In Africa, the burden is considerably higher at 50 DALY per 100,000 people. This study covers a small number of known pathogens and is likely to underestimate burden. Historical studies and outbreak investigations suggest that between 14 and $25 \%$ of all cases of identified FBD are related to dairy. Depending on the hazard and method, quantitative microbial risk assessment gives even higher estimates, but these may be inflated. This high disease burden corresponds to a high economic burden. Taking a conservative estimate of $4 \%$ of the FBD, it would correspond to around US $\$ 4$ billion/yr in poor countries and warrants greater investment in assessing, communicating, and managing dairyborne disease. There are many successful and promising approaches for reducing the burden of dairyborne disease, but caution should be used in their application to avoid unintended consequences such as disempowerment of women or reducing access to dairy. For example, there are many documented cases in which women's control over livestock is diminished with increasing commercialization (Kristjanson et al., 2010).

\section{ACKNOWLEDGMENTS}

The authors have not stated any conflicts of interest. Travel to the meeting was funded by the American Dairy Science Association.

\section{REFERENCES}

Abraham, M., M. Pai, G. Kang, G. V. Asokan, S. R. Magesh, S. Bhattacharji, and B. S. Ramakrishna. 1997. An outbreak of food poisoning in Tamil Nadu associated with Yersinia enterocolitica. Indian J. Med. Res. 106:465-468.

Ahlberg, S., D. Grace, G. Kiarie, Y. Kirino, and J. Lindahl. 2018. A risk assessment of aflatoxin $\mathrm{M}_{1}$ exposure in low and mid-income dairy consumers in Kenya. Toxins (Basel) 10:348. https://doi.org/ 10.3390/toxins10090348.

Alonso, S., E. Muunda, S. Ahlberg, E. Blackmore, and D. Grace. 2018. Beyond food safety: Socio-economic effects of training informal dairy vendors. Kenya Glob. Food Secur. 18:86-92. https://doi.org/ $10.1016 /$ j.gfs.2018.08.006.

Alexandratos, N., and J. Bruinsma. 2012. World food and agriculture to 2030/50: The 2012 revision (03 No. 12). ESA Working Paper. FAO, Rome, Italy.

Bharathy, S., L. Gunaseelan, and K. Porteen. 2017. Exploring the potential hazard of Mycobacterium avium subspecies paratuberculosis as a cause for Crohn's disease. Vet. World 10:457-460. https://doi .org/10.14202/vetworld.2017.457-460. 
Britt, J. H., R. A. Cushman, C. D. Dechow, H. Dobson, P. Humblot, M. F. Hutjens, G. A. Jones, P. S. Ruegg, I. M. Sheldon, and J. S. Stevenson. 2018. Invited review: Learning from the future-A vision for dairy farms and cows in 2067. J. Dairy Sci. 101:3722-3741. https://doi.org/10.3168/jds.2017-14025.

Claeys, W. L., S. Cardoen, G. Daube, J. De Block, K. Dewettinck, K. Dierick, L. De Zutter, A. Huyghebaert, H. Imberechts, P. Thiange, Y. Vandenplas, and L. Herman. 2013. Raw or heated cow milk consumption: Review of risks and benefits. Food Control 31:251262. https://doi.org/10.1016/j.foodcont.2012.09.035.

Cornelsen, L., P. Alarcon, B. Häsler, D. D. Amendah, E. Ferguson, E. M. Fèvre, D. Grace, P. Dominguez-Salas, and J. Rushton. 2016. Cross-sectional study of drivers of animal-source food consumption in low-income urban areas of Nairobi, Kenya. BMC Nutr. 2:70. https://doi.org/10.1186/s40795-016-0109-z.

Costard, S., L. Espejo, H. Groenendaal, and F. J. Zagmutt. 2017. Outbreak-related disease burden associated with consumption of unpasteurized cow's milk and cheese, United States, 2009-2014. Emerg. Infect. Dis. 23:957-964. https://doi.org/10.3201/eid2306 .151603 .

Currier, R. W., and J. A. Widness. 2018. A brief history of milk hygiene and its impact on infant mortality from 1875 to 1925 and implications for today: A review. J. Food Prot. 81:1713-1722. https: //doi.org/10.4315/0362-028X.JFP-18-186.

DAHD (India Department of Animal Husbandry and Dairying). 2020. Cattle and dairy development. Accessed Mar. 31, 2020. http://www .dahd.nic.in/about-us/divisions/cattle-and-dairy-development.

Devleesschauwer, B., A. H. Havelaar, C. Maertens de Noordhout, J. A. Haagsma, N. Praet, P. Dorny, L. Duchateau, P. R. Torgerson, H. Van Oyen, and N. Speybroeck. 2014. DALY calculation in practice: A stepwise approach. Int. J. Public Health 59:571-574. https: //doi.org/10.1007/s00038-014-0553-y.

Dror, D. K., and L. H. Allen. 2011. The importance of milk and other animal-source foods for children in low-income countries. Food Nutr. Bull. 32:227-243. https://doi.org/10.1177/156482651103200307.

EFSA (European Food Safety Authority). 2020. Risk assessment of aflatoxins in food. EFSA J. 18:1640.

FAO (Food and Agriculture Organization of the United Nations). 2020. Gateway to dairy products. Accessed Mar. 31, 2020. http: //www.fao.org/dairy-production-products/production/dairy -animals/en/.

FAO (Food and Agriculture Organization of the United Nations) and CARE. 2019. Good practices for integrating gender equality and women's empowerment in climate-smart agriculture programmes. Accessed May 2020. http://www.fao.org/3/ca3883en/ca3883en .pdf.

FDA (Food and Drug Administration). 2011. Grade "A" pasteurized milk ordinance. Revision 2011. FDA, Washington, DC.

Fratini, F., B. Turchi, M. Ferrone, A. Galiero, R. Nuvoloni, B. Torracca, and D. Cerri. 2016. Is Leptospira able to survive in raw milk? Study on the inactivation at different storage times and temperatures. Folia Microbiol. (Praha) 61:413-416. https://doi.org/10 $.1007 / \mathrm{s} 12223-016-0452-0$

Garbaj, A. M., E. M. Awad, S. M. Azwai, S. K. Abolghait, H. T. Naas, A. A. Moawad, F. T. Gammoudi, I. Barbieri, and I. M. Eldaghayes. 2016. Enterohemorrhagic Escherichia coli O157 in milk and dairy products from Libya: Isolation and molecular identification by partial sequencing of $16 \mathrm{~S}$ rDNA. Vet. World 9:1184-1189. https://doi.org/10.14202/vetworld.2016.1184-1189.

Gibb, H. J., A. Barchowsky, D. Bellinger, P. M. Bolger, C. Carrington, A. H. Havelaar, S. Oberoi, Y. Zang, K. O'Leary, and B. Devleesschauwer. 2019. Estimates of the 2015 global and regional disease burden from four foodborne metals - arsenic, cadmium, lead and methylmercury. Environ. Res. 174:188-194. https://doi.org/10 $.1016 /$ j.envres.2018.12.062.

Gizachew, D., B. Szonyi, A. Tegegne, J. Hanson, and D. Grace. 2016. Aflatoxin contamination of milk and dairy feeds in the Greater Addis Ababa milk shed, Ethiopia. Food Control 59:773-779. https: //doi.org/10.1016/j.foodcont.2015.06.060.

Gkogka, E., M. W. Reij, A. H. Havelaar, M. H. Zwietering, and L. G. Gorris. 2011. Risk-based estimate of effect of foodborne diseases on public health, Greece. Emerg. Infect. Dis. 17:1581-1590. https: //doi.org/10.3201/eid1709.101766.

Glynn, J. R., and D. J. Bradley. 1992. The relationship between infecting dose and severity of disease in reported outbreaks of salmonella infections. Epidemiol. Infect. 109:371-388. https://doi.org/ $10.1017 /$ S0950268800050366.

Grace, D. 2017. Food safety in developing countries: Research gaps and opportunities. White paper. International Livestock Research Institute, Nairobi, Kenya.

Grace, D., P. Dominguez-Salas, S. Alonso, M. Lannerstad, E. Muunda, N. Ngwili, A. Omar, M. Khan, and E. Otobo. 2017a. The influence of livestock-derived foods on the nutrition of mothers and infants during the first 1,000 days of a child's life. Research Report 44 International Livestock Research Institute, Nairobi, Kenya.

Grace, D., J. Lindahl, E. Kang'ethe, and J. Harvey. 2017b. Detecting and preventing contamination of dairy cattle feed. Pages 95-116 in Achieving Sustainable Production of Milk. Volume 2: Safety, Quality and Sustainability. N. van Belzen, ed. Burleigh Dodds Science Publishing Ltd., Cambridge, UK.

Grace, D., J. Monda, N. Karanja, T. F. Randolph, and E. K. Kang'ethe. 2012. Participatory probabilistic assessment of the risk to human health associated with cryptosporidiosis from urban dairying in Dagoretti, Nairobi, Kenya. Trop. Anim. Health Prod. 44(S1):S33-40. https://doi.org/10.1007/s11250-012-0204-3.

Grace, D., A. Omore, T. Randolph, E. Kang'ethe, G. W. Nasinyama, and T. Mohammed. 2008a. Assessment for Escherichia coli O157:H7 in marketed unpasteurized milk in selected East African countries. J. Food Prot. 71:257-263. https://doi.org/10.4315/0362 $-028 \mathrm{X}-71.2 .257$.

Grace, D., T. Randolph, N. Karanja, and E. Kang'ethe. 2008b. Modular process risk models for better management of Cryptosporidium parvum-An emerging zoonotic pathogen. Bull. Anim. Health Prod. Afr. 56:13-18. https://doi.org/10.4314/bahpa.v56i1.32825.

Grace, D., T. Randolph, A. Omore, E. Schelling, and B. Bonfoh. 2007. Place of food safety in evolving pro-poor dairy policy in East and West Africa. Rev. Élev. Méd. Vét. Pays Trop. 60:153-162. https:/ /doi.org/10.19182/remvt.9967.

Grace, D., K. Roesel, E. Kang'ethe, B. Bassirou, and S. Theis. 2015. Gender roles and food safety in 20 informal livestock and fish value chains. IFPRI Discussion Paper 1489. International Food Policy Research Institute, Washington, DC

Grandjean, P. 2016. Paracelsus revisited: The dose concept in a complex world. Basic Clin. Pharmacol. Toxicol. 119:126-132. https:// doi.org/10.1111/bcpt.12622.

Grenov, B., and K. F. Michaelsen. 2018. Growth components of cow's milk: Emphasis on effects in undernourished children. Food Nutr. Bull. 39(Suppl.):S45-S53. https://doi.org/10.1177/ 0379572118772766.

Häsler, B., G. Msalya, M. Garza, K. Fornace, M. Eltholth, L. Kurwijila, J. Rushton, and D. Grace. 2018. Integrated food safety and nutrition assessments in the dairy cattle value chain in Tanzania. Glob. Food Secur. 18:102-113. https://doi.org/10.1016/j.gfs.2018 .05 .003 .

Harcourt-Brown, L., S. Alonso, J. Lindahl, H. Varnell, V. Hoffmann, and D. Grace. 2018. Regulatory compliance in the Kenyan dairy sector: Awareness and compliance among farmers and vendors. Project Note. International Food Policy Research Institute, Washington, DC.

Hassan, A. N., and J. F. Frank. 2011. Microorganisms associated with milk. Pages 447-457 in Encyclopedia of Dairy Science. Vol. 3. J. W. Fuquay, ed. Academic Press, San Diego, CA.

Havelaar, A. H., M. D. Kirk, P. R. Torgerson, H. J. Gibb, T. Hald, R. J. Lake, N. Praet, D. C. Bellinger, N. R. de Silva, N. Gargouri, N. Speybroeck, A. Cawthorne, C. Mathers, C. Stein, F. J. Angulo, and B. Devleesschauwer. 2015. World Health Organization global estimates and regional comparisons of the burden of foodborne disease in 2010. PLoS Med. 12:e1001923. https://doi.org/10.1371/ journal.pmed.1001923.

Headey, D. D., K. Hirvonen, and J. F. Hoddinott. 2017. Animal sourced foods and child stunting. Discussion Paper 1695. International Food Policy Research Institute, Washington, DC. 
Heine, R. G., F. AlRefaee, P. Bachina, J. C. De Leon, L. Geng, S. Gong, J. A. Madrazo, J. Ngamphaiboon, C. Ong, and J. M. Rogacion. 2017. Lactose intolerance and gastrointestinal cow's milk allergy in infants and children-Common misconceptions revisited. World Allergy Organ. J. 10:41. https://doi.org/10.1186/s40413 $-017-0173-0$.

Hoffmann, S., and T. D. Anekwe. 2013. Making Sense of Recent Costof- Foodborne-Illness Estimates. Economic Information Bulletin Number 118. U.S. Department of Agriculture, Economic Research Service, Washington, DC.

Hoffmann, S., B. Devleesschauwer, W. Aspinall, R. Cooke, T. Corrigan, A. Havelaar, F. Angulo, H. Gibb, M. Kirk, R. Lake, N. Speybroeck, P. Torgerson, and T. Hald. 2017. Attribution of global foodborne disease to specific foods: Findings from a World Health Organization structured expert elicitation. PLoS One 12:e0183641. https://doi.org/10.1371/journal.pone.0183641.

Huang, F., Y. Li, W. Yu, S. Jing, J. Wang, F. Long, Z. He, C. Yang, Y. Bi, W. Cao, C. Liu, X. Hua, and Q. Pan. 2016. Excretion of infectious hepatitis $\mathrm{E}$ virus into milk in cows imposes high risks of zoonosis. Hepatology 64:350-359. https://doi.org/10.1002/hep.28668.

Jaffee, S., S. Henson, L. Unnevehr, D. Grace, and E. Cassou. 2019. The safe food imperative: Accelerating progress in low- and middle-income countries. Agriculture and Food Series. World Bank, Washington, DC

Kaindi, D. M., E. Schelling, J. Wangoh, J. K. Imungi, Z. Farah, and L. J. Meile. 2011. Microbiological quality of raw camel milk across the Kenyan market chain. Glob. Sci. Books Food 5:79-83.

Kaitibie, K. D., S. Omore, A. Rich, and D. P. Kristjanson. 2010. Kenyan dairy policy change: Influence pathways and economic impacts. World Dev. 38:1494-1505. https://doi.org/10.1016/j .worlddev.2010.06.008.

Kang'ethe, E. K., and K. Lang'a. 2009. Aflatoxin B1 and M1 contamination of animal feeds and milk from urban centers in Kenya. Afr. Health Sci. 9:218-226.

Kateete, D. P., U. Kabugo, H. Baluku, L. Nyakarahuka, S. Kyobe, M. Okee, C. F. Najjuka, and M. L. Joloba. 2013. Prevalence and antimicrobial susceptibility patterns of bacteria from milkmen and cows with clinical mastitis in and around Kampala, Uganda. PLoS One 8:e63413. https://doi.org/10.1371/journal.pone.0063413.

Kensler, T. W., B. D. Roebuck, G. N. Wogan, and J. D. Groopman. 2011. Aflatoxin: A 50-year odyssey of mechanistic and translational toxicology. Toxicol. Sci. 120(Suppl. 1):S28-S48. https://doi .org/10.1093/toxsci/kfq283.

Khare, S., A. Tonk, and I. Rawat. 2018. Foodborne diseases outbreak in India: A review. Int. J. Food Sci. Nutr. 3:9-10.

Khlangwiset, P., G. S. Shephard, and F. Wu. 2011. Aflatoxins and growth impairment: A review. Crit. Rev. Toxicol. 41:740-755. https://doi.org/10.3109/10408444.2011.575766.

Kilelu, C., L. Klerkx, A. Omore, I. Baltenweck, C. Leeuwis, and J. Githinji. 2017. Value chain upgrading and the inclusion of smallholders in markets: Reflections on contributions of multi-stakeholder processes in dairy development in Tanzania. Eur. J. Dev. Res. 29:1102-1121. https://doi.org/10.1057/s41287-016-0074-z.

Kirino, Y., K. Makita, D. Grace, and J. Lindahl. 2016. Survey of informal milk retailers in Nairobi, Kenya and prevalence of aflatoxin M1 in marketed milk. Afr. J. Food Agric. Nutr. Dev. 16:1102211038. https://doi.org/10.18697/ajfand.75.ILRI05.

Kolo, F. B., F. O. Fasina, B. Ledwaba, B. Glover, B. B. Dogonyaro, H. van Heerden, A. A. Adesiyun, T. C. Katsande, I. Matle, and A. K. Gelaw. 2018. Isolation of Brucella melitensis from cattle in South Africa. Vet. Rec. 182:668.1-669. https://doi.org/10.1136/vr.k2450.

Kristjanson, P., A. Waters-Bayer, N. Johnson, A. Tipilda, J. Njuki, I. Baltenweck, D. Grace, and S. MacMillan. 2010. Livestock and women's livelihoods: A review of the evidence. Discussion Paper 20. International Livestock Research Institute, Nairobi, Kenya.

Kuboka, M. M., J. K. Imungi, L. Njue, F. Mutua, D. Grace, and J. F. Lindahl. 2019. Occurrence of aflatoxin M1 in raw milk traded in peri-urban Nairobi, and the effect of boiling and fermentation. Infect. Ecol. Epidemiol. 9:1625703. https://doi.org/10.1080/ 20008686.2019.1625703.
Kumari, S., and P. K. Sarkar. 2016. Bacillus cereus hazard and control in industrial dairy processing environment. Food Control 69:20-29. https://doi.org/10.1016/j.foodcont.2016.04.012.

Lanata, C. F., C. L. Fischer-Walker, A. C. Olascoaga, C. X. Torres, M. J. Aryee, and R. E. Black. 2013. Global causes of diarrheal disease mortality in children $<5$ years of age: A systematic review. PLoS One 8:e72788. https://doi.org/10.1371/journal.pone.0072788.

Langat, G., M. Tetsuhiro, T. Gonoi, V. Matiru, and C. Bii. 2016. Aflatoxin M1 contamination of milk and its products in Bomet County, Kenya. Adv. Microbiol. 06:528-536. https://doi.org/10.4236/aim .2016 .67053

Larsson, S. C., A. Crippa, N. Orsini, A. Wolk, and K. Michaelsson. 2015. Milk consumption and mortality from all causes, cardiovascular disease, and cancer: A systematic review and meta-analysis. Nutrients 7:7749-7763. https://doi.org/10.3390/nu7095363.

Li, M., A. H. Havelaar, S. Hoffmann, T. Hald, M. D. Kirk, P. R. Torgerson, and B. Devleesschauwer. 2019. Global disease burden of pathogens in animal source foods, 2010. PLoS One 14:e0216545. https://doi.org/10.1371/journal.pone.0216545.

Lindström, M. J. Myllykoski, S. Sivelä, and H. Korkeala. 2010. Clostridium botulinum in cattle and dairy products. Crit. Rev. Food Sci. Nutr. 50:281-304. https://doi.org/10.1080/10408390802544405.

Liu, Y., and F. Wu. 2010. Global burden of aflatoxin-induced hepatocellular carcinoma: A risk assessment. Environ. Health Perspect. 118:818-824. https://doi.org/10.1289/ehp.0901388.

Liverpool-Tasie, L. S., N. S. Turna, O. Ademola, A. Obadina, and F. Wu. 2019. The occurrence and co-occurrence of aflatoxin and fumonisin along the maize value chain in southwest Nigeria. Food Chem. Toxicol. 129:458-465. https://doi.org/10.1016/j.fct.2019.05 .008 .

Lozano, R., M. Naghavi, K. Foreman, S. Lim, K. Shibuya, and V. Aboyans. 2012. Global and regional mortality from 235 causes of death for 20 age groups in 1990 and 2010: A systematic analysis for the Global Burden of Disease Study 2010. Lancet 380(9859):20952128. https://doi.org/10.1016/S0140-6736(12)61728-0.

Makita, K., F. Desissa, A. Teklu, G. Zewde, and D. Grace. 2012. Risk assessment of staphylococcal poisoning due to consumption of informally-marketed milk and home-made yoghurt in Debre Zeit, Ethiopia. Int. J. Food Microbiol. 153:135-141. https://doi.org/10 .1016/j.ijfoodmicro.2011.10.028.

Matofari, J. W., P. L. Shalo, M. Younan, J. N. Nanua, A. Adongo, and B. N. Misiko. 2013. Analysis of microbial quality and safety of camel (Camelus dromedarius) milk chain and implications in Kenya. J. Agric. Ext. Rural Dev. 5:50-54.

McDaniel, C. J., D. M. Cardwell, R. B. Moeller Jr., and G. C. Gray. 2014. Humans and cattle: A review of bovine zoonoses. Vector Borne Zoonotic Dis. 14:1-19. https://doi.org/10.1089/vbz.2012 .1164 .

McLinden, T., J. M. Sargeant, M. K. Thomas, A. Papadopoulos, and A. Fazil. 2014. Component costs of foodborne illness: A scoping review. BMC Public Health 14:509. https://doi.org/10.1186/1471 -2458-14-509.

Moh, L. G., L. P. Keilah, P. T. Etienne, and K. Jules-Roger. 2017. Seasonal microbial conditions of locally made yoghurt (shalom) marketed in some regions of Cameroon. Int. J. Food Sci. 2017:5839278. https://doi.org/10.1155/2017/5839278.

Motala, C., and A. Fiocchi. 2011. Cow's milk allergy in children. Accessed May 2020. https://www.worldallergy.org/education -and-programs/education/allergic-disease-resource-center/ professionals/cows-milk-allergy-in-children.

Mozaffarian, D. 2019. Dairy foods, obesity, and metabolic health: The role of the food matrix compared with single nutrients. Adv. Nutr. 10:917S-923S. https://doi.org/10.1093/advances/nmz053.

Nguyen-Viet, H., S. Dang-Xuan, P. Pham-Duc, K. Roesel, N. M. Huong, T. Luu-Quoc, P. V. Hung, N. T. D. Nga, L. Lapar, F. Unger, B. Häsler, and D. Grace. 2019. Rapid integrated assessment of food safety and nutrition related to pork consumption of regular consumers and mothers with young children in Vietnam. Glob. Food Secur. 20:37-44. https://doi.org/10.1016/j.gfs.2018.12.003.

Nishimwe, K., E. Bowers, J. D. Ayabagabo, R. Habimana, S. Mutiga, and D. Maier. 2019. Assessment of aflatoxin and fumonisin contamination and associated risk factors in feed and feed ingredi- 
ents in Rwanda. Toxins (Basel) 11:270. https://doi.org/10.3390/ toxins 11050270 .

Ntuli, V., P. M. K. Njage, P. Bonilauri, A. Serraino, and E. M. Buys. 2018. Quantitative risk assessment of hemolytic uremic syndrome associated with consumption of bulk milk sold directly from producer to consumer in South Africa. J. Food Prot. 81:472-481. https://doi.org/10.4315/0362-028X.JFP-17-199.

Ogot, H., H. O. Ochuodho, and R. Machoka. 2015. Microbial Analysis of raw and boiled milk sold at Baraton Center in Nandi County, Kenya. Baraton Interdiscip. Res. J. 5:113-117.

Ondieki, G. K., J. N. Ombui, M. Obonyo, Z. Gura, J. Githuku, A. B. Orinde, and J. K. Gikunju. 2017. Antimicrobial residues and compositional quality of informally marketed raw cow milk, Lamu West Sub-County, Kenya, 2015. Pan Afr. Med. J. 28(Supp 1):5. https://doi.org/10.11604/pamj.supp.2017.28.1.9279.

Orregård, M. 2013. Quality analysis of raw milk along the value chain of the informal milk market in Kiambu County, Kenya. Swedish University of Agricultural Sciences, Uppsala, Sweden.

Orwa, J. D., J. W. Matofari, P. S. Muliro, and P. Lamuka. 2017. Assessment of sulphonamides and tetracyclines antibiotic residue contaminants in rural and peri urban dairy value chains in Kenya. Int. J. Food Contam. 4:5. https://doi.org/10.1186/s40550-017-0050-1.

Painter, J. A., T. Ayers, R. Woodruff, E. Blanton, N. Perez, R. M. Hoekstra, P. M. Griffin, and C. Braden. 2009. Recipes for foodborne outbreaks: A scheme for categorizing and grouping implicated foods. Foodborne Pathog. Dis. 6:1259-1264. https://doi.org/ 10.1089/fpd.2009.0350.

Parra-Flores, J., F. Cerda-Leal, A. Contreras, N. Valenzuela-Riffo, A. Rodríguez, and J. Aguirre. 2018. Cronobacter sakazakii and microbiological parameters in dairy formulas associated with a food alert in Chile. Front. Microbiol. 9:1708. https://doi.org/10.3389/ fmicb.2018.01708.

Peters, C. J., J. Picardy, A. F. Darrouzet-Nardi, J. L. Wilkins, T. S. Griffin, and G. W. Fick. 2016. Carrying capacity of U.S. agricultural land: Ten diet scenarios. Elementa 4:000116. https://doi.org/ 10.12952/journal.elementa.000116.

Pires, S. M., A. R. Vieira, T. Hald, and D. Cole. 2014. Source attribution of human salmonellosis: An overview of methods and estimates. Foodborne Pathog. Dis. 11:667-676. https://doi.org/10 .1089 /fpd.2014.1744.

Pires, S. M., A. R. Vieira, E. Perez, D. L. F. Wong, and T. Hald. 2012. Attributing human foodborne illness to food sources and water in Latin America and the Caribbean using data from outbreak investigations. Int. J. Food Microbiol. 152:129-138. https://doi.org/10 .1016/j.ijfoodmicro.2011.04.018.

Raslan, A. A., S. Elbadry, and W. S. Darwish. 2018. Estimation and human health risk assessment of organochlorine pesticides in raw milk marketed in Zagazig City, Egypt. J. Toxicol. 2018:3821797. https://doi.org/10.1155/2018/3821797.

Roesel, K., F. Ejobi, M. Dione, D. Pezo, E. Ouma, J. Kungu, P.-H. Clausen, and D. Grace. 2019. Knowledge, attitudes and practices of pork consumers in Uganda. Glob. Food Secur. 20:26-36. https:/ /doi.org/10.1016/j.gfs.2018.12.001.

Rogawski, E. T., J. Liu, J. A. Platts-Mills, F. Kabir, P. Lertsethtakarn, and M. Siguas. 2018. Use of quantitative molecular diagnostic methods to investigate the effect of enteropathogen infections on linear growth in children in low-resource settings: Longitudinal analysis of results from the MAL-ED cohort study. Lancet Glob. Health 6:e1319-e1328. https://doi.org/10.1016/S2214 $-109 X(18) 30351-6$.

Sang, X. L., X. C. Liang, Y. Chen, J. D. Li, J. G. Li, L. Bai, and J. Y. Sun. 2014. Estimating the burden of acute gastrointestinal illness in the community in Gansu Province, northwest China, 2012-2013. BMC Public Health 14:787. https://doi.org/10.1186/1471-2458-14 $-787$.

Scallan, E., P. M. Griffin, F. J. Angulo, R. V. Tauxe, and R. M. Hoekstra. 2011. Foodborne illness acquired in the United States-Unspecified agents. Emerg. Infect. Dis. 17:16-22. https://doi.org/10 .3201/eid1701.P21101.

Sharma, D., and A. Malik. 2012. Incidence and prevalence of antimicrobial resistant Vibrio cholerae from dairy farms. Afr. J. Microbiol. Res. 6:5331-5334.
Sirma, A. J., J. F. Lindahl, K. Makita, D. Senerwa, N. Mtimet, E. K. Kang'ethe, and D. Grace. 2018. The impacts of aflatoxin standards on health and nutrition in sub-Saharan Africa: The case of Kenya. Glob. Food Secur. 18:57-61. https://doi.org/10.1016/j.gfs.2018.08 .001 .

Sirma, A. J., K. Makita, D. Grace, D. Senerwa, and J. F. Lindahl. 2019. Aflatoxin exposure from milk in rural Kenya and the contribution to the risk of liver cancer. Toxins (Basel) 11:469. https:// doi.org/10.3390/toxins11080469.

Spink, J., D. Ortega, C. Chen, and F. Wu. 2017. Food fraud prevention shifts the food risk focus to vulnerability. Trends Food Sci. Technol. 62:215-220. https://doi.org/10.1016/j.tifs.2017.02.012.

Stratton, J. E., R. W. Hutkins, and S. L. Taylor. 1991. Biogenic amines in cheese and other fermented foods: A review. J. Food Prot. 54:460-470. https://doi.org/10.4315/0362-028X-54.6.460.

Sudershan, R. V., R. Naveen Kumar, L. Kashinath, V. Bhaskar, and K. Polasa. 2014. Foodborne infections and intoxications in Hyderabad India. Epidemiol. Res. Int. 2014:942961. https://doi.org/10 $.1155 / 2014 / 942961$.

Thomas, M. K., R. Murray, L. Flockhart, K. Pintar, F. Pollari, A. Fazil, A. Nesbitt, and B. Marshall. 2013. Estimates of the burden of foodborne illness in Canada for 30 specified pathogens and unspecified agents, circa 2006. Foodborne Pathog. Dis. 10:639-648. https://doi.org/10.1089/fpd.2012.1389.

Vos, T., A. D. Flaxman, M. Naghavi, R. Lozano, C. Michaud, and M. Ezzati. 2012. Years lived with disability (YLDs) for 1160 sequelae of 289 diseases and injuries 1990-2010: A systematic analysis for the Global Burden of Disease Study 2010. Lancet 380(9859):21632196.

Wanjala, G. 2017. Microbiological quality and safety of raw and pasteurized milk marketed in and around Nairobi region. Afr. J. Food Agric. Nutr. Dev. 17:11518-11532. https://doi.org/10.18697/ ajfand.77.15320.

Weldeabezgi, L. T., T. W. Atsbha, H. H. Kassegn, T. F. Gebremichael, and M. H. Berhe. 2020. A quantitative risk assessment model for Staphylococcus aureus and Salmonella associated with consumption of informally marketed milk products in Tigray, Ethiopia. J. Food Saf. 40:e12749. https://doi.org/10.1111/jfs.12749.

Worku, T., E. Negera, A. Nurfeta, and H. Welearegay. 2012. Microbiological quality and safety of raw milk collected from Borana pastoral community, Oromia regional state. African J. Food Sci. Technol. 3:213-222.

World Health Organization. 2017. Health statistics and information systems: Global health estimates for 2000-2015. Accessed Jan. 30, 2020. http://www.who.int/healthinfo/global_burden_disease/ estimates/en/.

Wu, F. 2004. Mycotoxin risk assessment for the purpose of setting international regulatory standards. Environ. Sci. Technol. 38:40494055. https://doi.org/10.1021/es035353n.

Wu, F. 2015. Global impacts of aflatoxin in maize: Trade and human health. World Mycotoxin J. 8:137-142. https://doi.org/10.3920/ WMJ2014.1737.

Wu, F., J. D. Groopman, and J. J. Pestka. 2014. Public health impacts of foodborne mycotoxins. Annu. Rev. Food Sci. Technol. 5:351372. https://doi.org/10.1146/annurev-food-030713-092431.

Wu, F., and N. Saha Turna. 2019. Aflatoxin M1 occurrence in dairy products worldwide: Summary of literature review and policy implications. Feed the Future Innovation Lab for Food Security Policy, Research Paper 153. US Agency for International Development, Washington, DC.

Zhang, W. W., Y. Hu, G. He, Y. Zhou, L. Hong, and J.-G. Ding. 2019. Rat bite fever caused by Streptobacillus moniliformis infection in a Chinese patient. BMC Infect. Dis. 19:637. https://doi.org/10 .1186/s12879-019-4281-z.

\section{ORCIDS}

F. Wu (1) https://orcid.org/0000-0003-0493-0451

A. H. Havelaar $\odot$ https://orcid.org/0000-0002-6456-5460 